\title{
Problematic, disturbing and non-conforming children's behaviors: the concepts and care demands related to agitation in children in Santos and Campinas, Brazil'
} Comportamentos infantis problemáticos, perturbadores e não conformes: conceitos e demandas de cuidado relacionados à agitação em crianças em Santos e Campinas, Brasil

\author{
Eunice Nakamura ${ }^{a}$ \\ (iD) https://orcid.org/0000-0001-8786-5207 \\ E-mail: eunice_nakamuraळhotmail.com

\section{Tatiana Barbarini ${ }^{a}$} \\ (D) https://orcid.org/0000-0003-1827-2170 \\ E-mail: tati.barbariniðgmail.com
}

aUniversidade Federal de São Paulo. Laboratório Interdisciplinar Ciências Humanas, Sociais e Saúde. Santos, SP, Brasil.

\section{Correspondence}

Eunice Nakamura

Universidade Federal de São Paulo, Campus Baixada Santista, Departamento de Políticas Públicas e Saúde Coletiva. Rua Silva Jardim, 136. Santos, SP, Brasil. CEP 11015-021.

\section{Abstract}

This article discusses the social consequences of the impossibility of specifically defining the boundaries of the concept of mental disorder, which seems to be a "vague" term with no satisfactory definition, especially when referred to children's behaviors. We argue that when discussing children's problematic, disturbing or non-conforming behaviors it is necessary to understand how these concepts are related to the classificatory categories of children's behaviors and presented as care demands, whether in common sense or in biomedical discourses. Data were collected in qualitative research developed in three different child mental health services (CMHS), one in Santos (2012) and two in Campinas (2009-2010; 2017-2018), Brazil. Based on what seems to be a relation between biological-psychological dysfunction and social-cultural expectation or response, our starting point is that agitation is also a multidimensional and vague category, presenting a description and theoretical reflection about the various concepts regarding agitation. The analysis focuses on the different uses of the concepts of agitation; the social actors and institutions involved in care demands and how they are interdependently

\footnotetext{
1 The results presented in this article are part of three different studies. The data of Santos are part of the research "Social and cultural meanings of childhood mental health problems in Santos, Brazil, and Paris, France: contemporary representations of children”, carried out in Cermes3 at the University of Paris, France, in 2013, under the supervision of Alain Ehrenberg funded by the National Council of Technological and Scientific Development (CNPq-Brazil). The data of Campinas refer to the studies "The control of childhood: ways of the medicalization" and "The network of demand and care in child mental health - Social, family, school and health relations around the problems of child learning and conduct”, funded by the São Paulo Research Foundation (FAPESP-Brazil) and the National Council of Technological and Scientific Development (CNPq-Brazil), respectively.
} 
connected; then revealing, from a sociocultural perspective, the implications of classifying and defining children's behavior from this vague category.

Keywords: Agitation; Child; Childhood; Child Behavior; Sociocultural Perspective.

\section{Resumo}

Este artigo se inicia com um questionamento sobre as consequências sociais da impossibilidade de delimitar o conceito de transtorno mental, o qual parece ser um termo "vago", sem definições satisfatórias, sobretudo quando associado a comportamentos infantis. Argumenta-se que, para pensar os comportamentos infantis problemáticos, perturbadores ou não conformes, é necessário entender quais são os conceitos relacionados às categorias classificatórias dos comportamentos infantis e apresentados como demandas de cuidado, tanto no discurso do senso comum quanto no discurso biomédico. Os dados foram coletados a partir de pesquisas qualitativas desenvolvidas em três diferentes serviços de saúde mental infantil, um em Santos (2012) e dois em Campinas (2009-2010 e 2017-2018). Baseado no que parece ser uma relação entre disfunção biológico-psicológica e expectativa ou resposta sociocultural, toma-se como ponto de partida a agitação como uma categoria multidimensional e vaga, apresentando-se uma descrição e reflexão teórica sobre os vários conceitos relativos à agitação. A análise é centrada nos diferentes usos dos conceitos de agitação, os atores sociais e instituições envolvidos nas demandas de cuidado e as formas como eles estão interdependentemente conectados. Por fim, revela, a partir de uma perspectiva sociocultural, as implicações de classificar e definir o comportamento infantil com base em uma categoria vaga.

Palavras-chave: Agitação; Criança; Infância; Comportamento Infantil; Perspectiva Sociocultural.

\section{Introduction}

The fifth edition of the Diagnostic and Statistical Manual of Mental Disorders (DSM-5) (APA, 2013) describes all valid mental disorder symptoms, which guide the psychiatric diagnoses from grouping symptoms. However, those symptoms are considered as such to be associated to impairments in the patient's life, not physiological disorders. In other words, those problems are identified as mental disorders when they are associated with impairments in cognitive, psychological and social aspects of life.

Impairment, distress, or significant disturbance in cognitive, psychological and social aspects is the main principle of (child) mental disorders. Even if the DSM's definition of mental disorders emphasizes these aspects, it tries to distinguish biological-psychological dysfunction from a socialcultural expectation or response. However, is this attempt successful? Are the symptoms of mental disorders impairments actually distinguishable from sociocultural models of proper behavior?

The notion of mental disorder was created to distinguish a psychosocial distress condition from a biomedical condition characterized by a clear organic, physiological, and anatomical basis. However, "mental disorder" seems to be a "vague" term that has no satisfactory definition capable of establishing boundaries to it.

However, this issue is not restricted to DSM-5, since the previous version of the Manual (DSM-4) is also criticized for being based on "quite ambiguous clinical symptoms", which possibly led to an increase in the number of diagnoses mainly from the $1990 \mathrm{~s}$ (Caponi, 2014, p. 743). The author emphasizes some studies that criticize DSM-5, pointing out the maintenance of "great epistemological frailties, limited to listing unclear symptoms to an increasing set of mental pathologies" (Caponi, 2014, p. 742, authors' translation).

Such criticisms seem to be more problematic when considering some mental disorders related to children's behaviors, since they depend on what is considered a problematic, disturbing or non-conforming behavior, according to adults' views (Nakamura, 2016). Thus, this article begins with the following question: what are the social consequences of the impossibility of defining 
the boundaries of the concept of mental disorder in children, especially between their normal, abnormal or pathological behaviors?

Agitation is the main subject of this article, from which we will try to answer that question. This term is related to different common-sense concepts (e.g., hyperactivity, turbulence, disturbance, unquietness, among others) as well as to psychiatric categories (e.g., Attention Deficit Hyperactivity Disorder, Conduct Disorder and Oppositional Defiant Disorder). The term "agitation" indicates the representation of many different children's behaviors considered to be problems, as it seems to happen with other mental disorders in children, such as depression - also considered to be broad and vague, with blurred frontiers between biomedical and common-sense categories; thus being imprecise and non-specific (Nakamura, 2016, p. 107).

From this question, we shall present a theoretical discussion based on the idea that what we define as normality is impregnated with social values, followed by the normal, the abnormal, and the pathological that does not specifically correspond to biomedical constructs but are related to a health norm socially defined, i.e., they are in conformity with a social order (Canguilhem, 1978). In this sense, thinking about children's problematic, disturbing or non-conforming behaviors lead us to understand which concepts are related to the classificatory categories of children's behaviors and presented as care demands, whether in popular or biomedical discourses. The discussion is based on the data collected in three different studies developed in the cities of Santos and Campinas, Brazil.

We deal with different realities concerning child mental health services (CMHS) in these Brazilian cities. Data analyzed were related to the first care demand presented by families, other adults and institutions to the CMHS, emphasizing those related to agitated behaviors and their representation according to the various social actors. The first complaints were considered in the analysis as a sort of social discourse in which technical and popular terms or categories are integrated to. Therefore, despite the particularities found in these contexts, our intent was to identify the categories used by different individuals to comprehend, classify and organize children's behavior, as well to resolve situations considered to be problems, i.e., to turn them into a specific model of normality.

Based on what seems to be a relation between biological-psychological dysfunction and socialcultural expectations or responses, we defined as a starting point that agitation is a multidimensional and vague category (Nakamura; Barbarini, 2017) that can indicate different types of "problematic", "disturbing" or "non-conforming" behaviors associated to children. Following, we shall describe and propose a theoretical discussion about the flow of discourses, knowledge and concepts regarding agitation that compose demands to health care networks, considering the various social actors and institutions involved. Given this context, this analysis is focused on the following questions: (1) How are 'agitation' - and other related terms - referred to in the discourses of health professionals?; (2) What are the relationships established between children's behaviors, social problems and psychiatric categories?

Firstly, we describe different uses of the agitation concept and analyze what representations of children's normal, abnormal, problematic or pathological behavior underlie these uses. Following, we delineate who are the social actors, and which are the institutions involved in care demands and how they are interdependently connected. Finally, we discuss, from a sociocultural perspective, the implications of classifying and defining children's behavior from this vague category.

\section{Methods}

Data were collected via qualitative research developed in two Brazilian cities, Santos and Campinas. The fieldwork was conducted in three child mental health services (CMHS), ${ }^{2}$ one of them in Santos and the other two in Campinas,

2 We call CMHS the child mental health services where the researches were conducted, although they refer to different care levels in each city. In Santos, the research was made in a child health care center which focused on promoting children's and adolescents' mental health. In Campinas, the studies were conducted in a child psychiatric hospital (CMHS1) (Barbarini, 2011) and in a child psychosocial 
for an in-depth investigation in these contexts, understanding their particularities and the different concepts related to children's behavior, specifically agitation. These studies were comparatively analyzed for the discussion proposed in this article.

The research in Santos was carried out in a CMHS in 2012 and focused on the patients' records and in-depth interviews with health professionals. In Campinas, one CMHS (CMHS1) was visited from 2009 to 2010, the fieldwork consisting on observation and in-depth interviews with health professionals, families and children with Attention Deficit Hyperactivity Disorder (ADHD). The other CMHS in Campinas (CMHS2) was visited from 2017 to 2018 and comprised the analysis of the patients' records and the observation of the meetings of the health professionals team; some informal conversations were also registered.

The patients' records were considered documents that include thoughts, meanings, judgements and acts, and according to two complementary approaches: as a resource and as a topic. The first approach focuses on what was "in" the document, revealing the adults' representations of agitation related to their descriptions of the children's behavior; the second approach emphasizes the document's functioning and its impact on social interaction schemes (Silverman, 2010).

The patients' records analyzed in the different contexts were composed by different documents from various institutions (school, health care centers, social assistance, and specialized mental health services) and were also produced by professionals from each CMHS (anamnesis, family history, case evolution). The first complaints were registered in a form in the CMHS' reception and filled by the professional who first received the patient according to information given by the family, especially mothers.

For an in-depth approach of these contexts, the comprehension of its particularities and of the different perceptions and ways of dealing with children's behaviors, the observation in the CMHS, informal conversations and in-depth interviews using a semi-structured guide were prioritized to enable contact with the different realities experienced by health professionals, as well as their understanding and representations (Cardoso de Oliveira, 2006), especially regarding agitated behaviors.

\section{Comparing different research contexts}

The research carried out in Santos, a city in the state of São Paulo, in 2012 took as its starting point the experiences of children who received care from a CMHS, the way their behaviors, especially those referred as 'agitation', were perceived by adults at school, the health services and their homes, being presented as a complaint to this health service. The perceptions of children's behavior at school were described in the in the patients' records as reported by the parents or they were mentioned in the interviews by the health professionals.

This CMHS team was composed of psychologists, speech therapists, occupational therapists, physical therapists, psychiatrists, social workers, mid-level technicians (therapeutic assistants) and administrative staff.

The data collected from the patients' records in the Santos CMHS involved children up to 11 years old, the age limit for the CMHS, who received care in 2012. Six health professionals were interviewed: three psychologists, one social worker, one speech therapist and one service manager.

In Campinas, also in the state of São Paulo, the research developed at CMHS1 from 2009 to 2010 and aimed to understand the reason why some children's behaviors, such as hyperactivity, were classified as symptoms of a mental disorder. On the other hand, the research at CMHS2, conducted from 2017 to 2018, aimed to analyze the network of demands and care in child mental health involving the concept of "agitation".

Data were collected at CMHS1 from semistructured interviews with two psychiatrists, one psychologist, four mothers and their children

care center (CMHS2). Despite the structural particularities and differences in approaching child mental health in these services, we were interested in analyzing the circulation of concepts and actors towards a common phenomenon: the discourses based on the ideas of "agitation". 
diagnosed with Attention Deficit Hyperactivity Disorder (ADHD) - three boys (12, 10 and 9 years old) and one girl (11 years old). The children also participated in informal conversation and drawing making. This article analyzes the children's interviews and informal conversation as part of the production of their identities.

The fieldwork performed at CMHS2 was based on the observation of meetings between professionals once a week, informal conversation with health professionals (psychologists, speech therapists, psychiatrists, pediatricians, occupational therapists, nurses, social educators), and analysis of new patients' records, of children from 3 to 12 years old.

The descriptions of complaints about agitation in the patients' records and mentioned in the interviews and informal conversation with the health professionals were analyzed as discourses, being grouped by categories to allow the identification of who said each information and what the adults said about agitation.

The analysis highlighted the main questions regarding what is considered agitation related to children's behavior, and who are the main social actors and institutions that present it as a problem to the different CMHS.

\section{Agitation as a problem addressed to CMHS}

The CMHS in Santos was responsible for caring about 300 children in 2012, from which 112 records were analyzed according to the aims of this research.

All the descriptions registered in the 112 patients' records were read as narratives of the different social actors or of the adults who presented the problems, to analyze the problems and complaints related to children's behavior. These narratives allowed us to identify some common categories in the CMHS and to relate them to the social actors in the service. Thus, both those who spoke and what they said about the children's behavior were identified.

Among the 112 analyzed records, 77 were boys $(68.8 \%)$ and 35 were girls (31.2\%). Most children (70) were within the 6-11 years age group, 39 children were 3 to 5 years old, and it should be noted that 3 children were 2 years old, $62.5 \%, 34.8 \%$ and $2.7 \%$, respectively. Agitation was mentioned in only 8 of the children's records (7.1\%), but when associated with the difficulty of concentration and attention, 16 complaints (14.3\%) were found.

In Campinas, a survey carried out in 2010 by the professionals of the CMHS1 showed that-, from a total of 180 patients, 41 patients (22.8\%) between 5 and 14 years old were diagnosed with $\mathrm{ADHD}$, according to the International Statistical Classification of Diseases, 1oth (ICD-10) criteria (OMS, 2008).

At CMHS2, from March to April 2018, 50 patients' records of children from 3 to 12 years old were analyzed. The terms "agitation" or "agitated" were presented as the initial complaint (34\%), especially among children from 6 to 9 years old (9 records out of 18 , and $55.6 \%$ were boys) and from 10 to 12 years old ( 6 records out of 14 , and $83.3 \%$ were boys).

Considering these general data on children who received care in the mental health services, most of them were boys in the elementary school age group and, although in small number, children under 3 years old.

By comparing the data from the three CMHS, we can note that, in addition to the higher prevalence of children in elementary school years, agitated behaviors are generally associated with boys. This profile (boys in elementary school) is presented in DSM-4 and DSM- 5 for describing the prevalence of ADHD; however, socio-anthropological studies point to an important “gender gap” (Hart; Grand; Riley, 20o6).

The DSM-5 states that many parents observe excessive motor activity in toddlers but that distinguishing Attention Deficit Hyperactivity Disorder (ADHD) symptoms from normative behaviors before 4 years old is difficult. Therefore, ADHD is most often identified during elementary school years' (APA, 2013, p. 62).

Studies indicate that ADHD is one of the most common diagnoses in childhood, with prevalence of 3 to $5 \%$ in school-age children and more frequently in boys (Andrade; Scheuer, 2004; Rohde; Halpern, 2004; Vasconcelos et al., 2003). Andrade and Scheuer (2004) show that the prevalence rate found in epidemiological studies in Brazil was from $3.6 \%$ to $5 \%$ of school-age population; thus, being similar to worldwide data. However, Vasconcelos et al. (2003, p. 68, authors' translation) note that "more recent 
studies have found higher prevalence rates, and more rigorous epidemiological studies have defined 4 to $12 \%$ rates among the general population of 6 to 12 years old children".

Considering the differences related to the care level and to the approaches regarding care practices, the particularities of each CMHS in Santos and Campinas may explain how agitation is presented as a vague behavior complaint about children or associated to a more precise ADHD diagnosis.

The Santos CMHS focuses on children's and adolescents' mental health, aiming at their emotional, social and intellectual development. By conceiving child care from an integral approach, an interdisciplinary team of health professionals seemed to be less oriented to perform a psychiatric diagnosis and more involved with social and psychosocial approaches to children's behaviors. This may explain the fact that the main problems identified in children were related to learning problems at school (language and speech problems, difficulty in accepting rules and orientations at school) than to agitation.

On the other hand, CMHS1, in Campinas, is a child psychiatry hospital and although its team was composed of different professionals such as psychiatrists, psychologists and social workers, its approach seemed to be oriented towards a biomedical care, which may explain the mentions to ADHD diagnoses. At CMHS2, a child psychosocial care center, the initial complaints related to agitation reported by people and institutions from outside the service were associated to hypotheses of ADHD or autistic spectrum disorder in patients' medical records, although the team adopted a different approach to handle the concept of agitation and agitated child behaviors.

Therefore, what is presented as the first complaint is related to who presented it, the particular characteristics of each CMHS, their orientation in child care and the perspectives of the professionals involved.

\section{The various concepts related to agitation}

The idea of agitation seems to be an important change observed by adults in children's behavior, as described in the patients' records in the CMHS in Santos. The behavior is not described as simply agitation, but as 'extreme and excessive agitation'. We shall emphasize that the degree (excessive) attributed to this kind of behavior allowed adults to differentiate it from what could be considered as a normal and acceptable form of agitation. The complaints registered in the patients' records referred to a child who was "very agitated" (bem agitado, muito agitado), "quite agitated" (bastante agitado) or "extremely agitated" (extremamente agitado). The adults who submitted the complaints emphasized a child who "fidgets too much" (agita-se demasiadamente) and presented "excessive agitation" (agitação excessiva).

The idea of agitation identified in the patients' records seems to reinforce the abnormality of this behavior, especially when related to greater degree, as mentioned above. The intensity attributed to agitation is what seems to make it into a problem and one of the main reasons for the requests submitted to the CMHS in Santos.

Agitation is also related to the ideas of a "disruptive" or "restless" (inquieta) child who "does not remain still” (não para, não fica parada) and "cannot remain sitting" (não consegue ficar sentada). Adults also relate agitation to "aggressiveness" (agressividade) and "instability" (instabilidade).

It is also important to note that, in some patients' records, the complaint about agitation is associated with difficulty of concentration and attention, seemingly as one of its consequences. Thus, an agitated child may present difficulties in concentrating and paying attention, and adults refer to such child as one who is "distracted" (dispersa) or "frequently distracted", who "does not concentrate" (não se concentra), "has no concentration" (não tem concentração) or has "minimal concentration" (pouca concentração), in other words, they describe a child who "does not pay attention" (to anything).

Similar characteristics were also observed in the interviews with health professionals from the same CMHS: a profusion of different terms related to the idea of agitation. According to a social worker and a speech therapist, adults complain about a child who is "restless" (irrequieta), "aggressive" (agressiva) and with concentration problems. 
We must note that despite few mentions of the biomedical categories of ADHD or hyperactivity being found in the patient's records, some adults referred to a "hyperactive child" (criança hiperativa), with "ADHD" or a child who presents a "high degree of hyperactivity” (alto grau de hiperatividade).

A social worker referred to these complaints presented by adults with a critical perspective. She stated that nowadays everyone is hyperactive, and then they think a child is too irritated, labelling her/ him as hyperactive.

A psychologist criticizes such trivialization of hyperactivity and ADHD as presented to the CMHS. According to her, when these children are examined by mental health professionals, these disorders are probably not going to be diagnosed: They [the adults] come with everything figured out. [...] The complaint is about ADHD, but it doesn't really exist. It may exist but it is very rare. If you take the complaints and analyze what ADHD is, you will see that it is not... [ADHD].

These different terms related to the idea of agitation and complemented by adjectives used to attribute to it a degree of abnormality refer to a specific children's behavior as described in the patients' records and mentioned by the interviewed professionals of the CMHS in Santos. We must note that these terms reveal the adults' representations of agitation related to their descriptions of children's behavior from everyday speeches, but in which we also could identify some categories from biomedical discourse (ADHD or hyperactivity), pointing to an ambiguous use of the biomedical category in the common sense.

Regarding Campinas, in CMHS1 agitation was profoundly connected to the idea of agitation as a categorical symptom of child mental disorders, especially ADHD. The diagnosis was established according to DSM-4 (DSM-5 had not been published at the time). The main discourse underlying the definition of agitation in this health service relating children's behavior and learning problems -, is based on categories of biomedical psychiatry and on the DSM, such as hyperactivity, impulsivity, and inattention. Individual characteristics and behavior are the basis to define a problematic manifestation:
The child we call hyperactive is not that shel he is ill and that she he is abnormal because of this, but it happens that due to her/his personal characteristics, for one reason or another, she he tends to not, as fast as other children, stop and pay attention. (Psychiatric doctor, 2009)

He also explains that pathology, in this sense, is not defined as a biological dysfunction, but a problem that causes suffering:

a mental disorder is pathological in the sense of pathos, of suffering, of not feeling well, it is not necessarily nosological, because not necessarily you will find an organic, structural substrate that determines that. ADHD is very much based on that.

From the fieldwork, we observed that despite the importance of the idea of suffering for multiprofessional practice, the psychiatric categories described in DSM-4 and ICD-10 and therapy based on psychostimulants and the biomedical approach were predominant in CMHS1, revealing its different approach when compared to $\mathrm{CMHS}_{2}$.

The psychoanalytic approach was dominant at $\mathrm{CMHS}_{2}$; the person is seen like an actor -a subject/individual -, and not merely as a case to be diagnosed.

The multidisciplinary group of professionals from CMHS2 used the term 'agitation' in a broad sense, not indicating a specific clinical category but specific actions and reactions, to comprehend what underlies such agitated behavior. Thus, agitation is considered part of children's particular manner to deal with suffering, not being reduced to his/her main characteristic. In other words, agitation - or psychomotor agitation - is the limit sign of a crisis, the moment when the child "comes to action" (passa ao ato). Differently from CMHS1, agitation is not related to normality, abnormality or pathology, but to the mental suffering that underlies an action. Therefore, some members of the CMHS2 team prefer to use the psychoanalytic term "subjective urgency" instead of "crisis" to designate the situation caused by "coming to action", which poses new questions and new actions to the people involved with the child. In other words, these conceptions of "agitation" and 
"crisis" attribute new meanings to the concept of subject or social actor, something that does not occur when the concept of agitation is used to indicate an abnormal or pathological behavior.

This kind of distinction could be also observed in the children's records, which are composed of documents from other institutions (school, health care centers) and professionals (psychiatrists, pediatricians, social workers), and by documents produced in CMHS2. Those documents generally reinforce the biomedical approach using categories related to the ideas of pathology and normality. On the other hand, documents produced by CMHS2 professionals were related to a psychoanalytic approach.

"Agitation" in the Santos CMHS is mostly related to children's behavior problems, seeming to be a concept that blurs the line between the common sense terms and the diagnostic categories. The concepts of "agitation" identified in the patients' records of this service and in the health professionals' interviews reveal such blur between the ideas of normal, abnormal and pathological as possibilities of transgression of a rule of health and, as our own complement, of a rule of adequate behavior, socially conceived in accordance with a given social order, in the terms presented by Canguilhem (1978).

Even when the concept of "agitation" is more clearly referred to a symptom of a diagnostic category like ADHD, as mentioned in CMHS1 in Campinas, it seems that we are dealing with a pathological condition that is also a transgression of a social norm. In this case, what is important for the clinicians is to diagnose and to provide therapy, i.e., "to return to the norm a function or an organism that was removed from it”. (Canguilhem, 1978, p. 94)

The limits between normal and non-normal, or abnormal children's behaviors can be differently defined according to the adopted perspective. Thus, agitation, misbehavior or learning difficulties can be associated with family structure, failure in school performance, and misbehavior - something that bothers people. In technical terms, these are externalizing behaviors. Specialists (both psychologists and psychiatrists from CMHS 1 in Campinas) affirmed that adults pay less attention to quiet children. However, these children are also suffering.
Agitation is also related to conceptions of "person" (Bustamante; McCallum, 2014) and to psychoanalytical approaches that consider the individual as an actor instead of a medical case or an abnormal behavior. These ideas can be observed in CMHS2 in Campinas, where professionals adopt a psychoanalytic approach of a child's psych suffering. Thus, "inadequate" behavior and school performance are not considered as transgressions of social norms but as actions that respond to something that causes suffering. Therefore, children are not considered passive individuals that disrupt an ideal model of child or childhood - or, in other words, the "normal" child/childhood; they are considered as active subjects or actors who also change the relationships around them.

The different concepts of agitation identified in the three CMHS refer to the adults' interpretations about children's behaviors, revealing how scientific, professional and institutional concepts are related, mixing popular and biomedical discourse.

On the one hand, the banalization of some biomedical categories can be found in the complaints presented, especially by families, but also in the speech of some professionals. The notion of banalization can be used as a referential term, from which different phenomena associated to children's behavior are named (Nakamura, 2016). On the other hand, speeches from professionals are not homogeneous regarding psychiatric categories, sometimes revealing a diffuse and unclear frontier between the normal and the pathological, between symptoms and diagnosis, between causes and consequences. These unstable and ambiguous frontiers between the different dimensions of a single concept (agitation) seem to ground the increase in the number of some diagnoses, as observed for hyperactivity in Brazil in recent years, suggesting a phenomenon that some authors call the "medicalization of conducts considered socially undesirable”. (Caponi, 2014, p. 744)

Therefore, agitation is then presented as a behavior problem in the CMHS in Santos; a symptom of ADHD in the CMHS1; a hypothesis of ADHD or autism in the CMHS2. The concept also appears as a cause of suffering (CMHS1) or a way of children to cope with suffering (CMHS2), depending on who was interviewed. 
Given this discussion, what is said about agitation cannot be separated from who said it.

\section{Interdependence and interchanges: social actors, institutions, knowledge and practices}

The classification of children and/or their behavior as normal, abnormal or pathological is not exclusively restricted to the medical area - specifically of psychiatry -, but a necessary organization of the experiences between adults and children. Therefore, regarding agitation, it is interesting to analyze who presented the initial request, i.e., who mentioned agitation as a problematic, disturbing or non-conforming behavior.

In the CMHS in Santos, we found that school professionals were those who mostly indicated agitation as a problem. Mainly teachers and educational counsellors ${ }^{3}$ from schools ${ }^{4}$ referred agitated children to this CMHS, but also other educational professionals of public or private schools. Their complaints were mainly about children who "disturbed the class" (perturba a classe) and "upset their classmates" (atrapalha os colegas) or those who present concentration and attention difficulties: "learning difficulty" and "does not perform the proposed activities".

A social worker who was interviewed emphasized the role of the school and its professionals in presenting requests to the CMHS about children with behavior problems in general, not only for agitated children: children who arrive here are usually referred by their school, where they have observed an abnormal situation, an impairment of the child.

Although schools seem not to succeed in solving problems related to agitated children - who may or may not present concentration and attention difficulties -, its professionals, especially the educational counsellor, are attentive to these "problematic" behaviors and their consequences in class for other children and to the learning process. Therefore, schools are the main demander to health services for agitated behavior, although families - especially mothers - are responsible for "taking care" of their children. According to Singh (2004, 2007) and Hart, Grand, and Riley (2006), like mothers, teachers (it is important to note that most teachers are women in elementary schools) play the fundamental role in identifying "problem" children.

Barbarini (2016) analyzed the educational conditions in Brazil to understand the increasing number of care demands coming from schools, especially when they are related to "agitated behavior". According to the author, several factors constitute what is called "the crisis of education" in the common sense: the social delegitimization of teachers and new emerging illnesses, like burnout syndrome, that afflict these professionals; changes in social and educational roles of teaching, leading to conflicts in families to define who is responsible for "educating" children; new childhood subjectivities - new forms of being a child -, that no longer correspond to a disciplinary structure that still constitutes contemporaryw schools. Within this scenario, teachers have affirmed in the study that they "feel impotent" to deal with "problematic behaviors" or learning difficulties, and demand specialized care from health or mental health professionals.

The transformation of school problems into "objects of health care" is not a contemporary phenomenon. In France, Pinell and Zafiropoulos (1978) suggested such shift, especially with the emergence of child psychiatry after the Second World War, one of the specialties that started to deal with "maladjusted children". According to the authors, a new cluster of activity for school issues was organized around psychoanalysis starting from the late 1960 s, with a psychological retranslation of a social phenomenon: the failure of workingclass children.

\footnotetext{
3 Brazilian public schools have educational counsellors responsible for ensuring the full involvement of students in the school environment, in addition to social support from other institutions and from the family.

4 In Brazil, children and adolescents from 4 to 17 years old must attend basic education which is divided into: "day care" and preschool, elementary school I ( $1^{\text {st }}$ to $5^{\text {th }}$ grade), elementary school II ( $6^{\text {th }}$ to $9^{\text {th }}$ grade), and high school ( $10^{\text {th }}$ to $12^{\text {th }}$ grade).
} 
Therefore, following the shift of children's behavior problems from the schools to mental health services, we can note a shift of the responsibilities, places and roles to regulate the behaviors of children.

Based on the notion of anomy proposed by Durkheim, Fernandes (1997) states that the school is presented as a solution to engender in children the elements of a morality in crisis; thus, expecting that school could be a solution provider to the social deviance caused by the lack of discipline. After being unsuccessful in the task for answering and solving problems, the school retranslates a social phenomenon into the psychological order (Pinell; Zafiropoulos, 1978), also transferring the responsibility of dealing with them to health services, but not without criticism.

A psychologist of the CMHS in Santos criticized the reasons for schools' requests for any children's behavior considered to be a problem:

the main referrers [of children] are schools. We did some mentoring work because they used to refer anything to us [the CMHS]. We told them we did not have a magic wand, we have a therapy process. Sending us an uneducated child is useless because we will not solve it [the problem].

However, we must consider that a school may start this process - the identification of a child's behavior as a (mental health) problem -, but this is only a part of a complex network involving health services, other institutions and social actors.

It is important to point that each CMHS has a different internal organization to receive demands regarding children's problematic behaviors. Some of them are directly connected to basic health centers, which are the "gateway" to the (mental) health system. Therefore, the first requests coming from schools are addressed to such basic centers and then to the CMHS. Other CMHS receive the demand directly from educational professionals. In both cases, schools are the main institution where child behavior is identified as a problem or not, as observed in the three studies analyzed comparatively in this article, but other institutions can also be involved in this network.

In the CMHS in Santos, agitation was also presented as a complaint by clinicians from other health services and by parents, particularly mothers. According to a social worker from this service, other institutions can be involved in this process: most [of the requests come from] the school, the Guardianship Board and the health services network [...] so this is the main flow: school, board and health units.

In the CMHS2 in Campinas, another important institution in identifying "problematic children" are shelters, especially when a child's case is being analyzed by judges and social workers, whose perceptions and judgments are based on the idea of "delinquent minor". According to the observation in the mental health professionals' meetings at CMHS2, those situations create a conflict between mental health and social assistance professionals due to their different perceptions on the child: on the one hand, he/she is considered as a subject with rights, on the other hand, he/she is treated as a delinquent or the product of a "dysfunctional" family or community.

In both CMHS in Campinas, few children's families were identified as demanders of mental health care for agitation cases, since schools were the main source of demands in the cases analyzed. However, parents and guardians play an intermediate role between the school's demand for specialized care and the public or private mental health services, revealing some conflicts in their relationship with the both institutions. On the one hand, school professionals ask the parents to explain and solve their children's behavior and learning problems, since parents are unable to accomplish such task, teachers demand from them a closer relationship with specialists to solve such problems. On the other hand, parents play an effective role in the psychiatrist-patient relationship, acting as a regulatory intermediary: they mobilize their own expectations, categories, and vocabulary to evaluate the psychiatrist's performance, as we noted in some interviews with mothers:

I saw no results. Instead of prescribing him some medication for concentration, she gave him tranquilizers. I asked his pediatrician myself to refer him to the university hospital. We already had some knowledge about the therapy offered there... for hyperactive children. (10-year-old boy's mother. October 2010) 
Doctors and psychologists are like priests and best friends: you must trust them. If you don't, it doesn't work. It doesn't work because you're going to take the medicine not believing in it. You're not going to have the courage to say everything you want to the doctor. (12-year-old boy's mother, February 2010)

The requests presented, particularly those by schools, seem to highlight a requirement for an investment in the child outside the family. However, this process is not restricted to schools but also involves health services, health specialists and other institutions. In this sense, it is not restricted to displacement for replacing one institution (school) by other (health service), but the constitution of a child-oriented network composed of interdependent institutions and social actors. Thus, the concept of interdependence allows us to analyze and comprehend the complexity of this network.

In these different investigation contexts, we note some evidences of the interdependence of a great number of actors and institutions - teachers, educational counselors, doctors, psychologists, social workers, families - who seem to gravitate around children, worrying about their behavior and their problems. This idea of interdependence, as presented by Norbert Elias (1991), points to a relative weakening of the almost exclusive role of parents and schools in children's education, in favor of other institutions and actors who have different views about children and the places and the roles that they must have in society. However, this does not refer to "modelling children as objects of adults' views and actions, as we must consider children themselves as parts of this social network that is constituted by adults and children" (Nakamura; Planche; Ehrenberg, 2018, p. 419). We must emphasize that such interdependent network implies an interchange between guardians (families or shelters), the school and health service professionals; an interchange that organizes the experiences involving adults and children according to the notions of problematic child ("maladjustment", "minor", "agitated"), but also between institutions, actors, knowledge and documents.

In the CMHS in Santos, when an educational counselor presents the complaint of an agitated child, he/she must present a report of this child's behavior at school. If such report is not provided, the health professional responsible for evaluating the child is required to ask for it. This is the onset of an institutional exchange between health and educational professionals based on reports, knowledge and practices focused on agitated children. From this moment, if a child is considered as a problematic case (not just agitated), the school is going to have a specific health professional as a referral in the CMHS. This referral professional is going to arrange meetings to discuss the cases of children referred to the CMHS with the educational counselor, usually every three months.

The institutional exchange between human actors through objects and knowledge leads us to the theoretical analysis proposed by Bruno Latour (2015), which is based on the idea that neither the object is a mere utensil for humans, nor the subject is just an objectified extension of objects when both are in a relationship. In other words, humans and nonhumans are both actors in the construction of social reality, and, as mediators, they affect each other and create a new action. In other words, as doctors or other health professionals create the "agitated profile" - or identity - based on what they write about children on their reports, these reports (re)organize conceptions and actions and "perform" the experiences involving adults and "agitated" children.

On the one hand, this interchange puts in action both humans and non-humans (Latour, 2015) in defining the profile, identities and experiences about "agitated" children. On the other, it shows that children are also actors who participate on social reality and perform their own experiences towards "agitation".

\section{What are the meanings and implications of defining children as agitated?}

The studies conducted in Santos and Campinas showed us the different concepts of agitation found in the common sense, in professionals' discourses and their relation (or not) with the symptoms and the diagnosis of ADHD or hyperactivity. These different concepts showed the need to consider the network established between social actors and institutions, their knowledge, practices and the documents produced from the various manners that adults 
deal with children's behaviors, in this specific case, agitation in a broad and vague sense.

The concepts of agitation circulate in this network interdependently and interchangeably, leading us to reflect about three points regarding the meanings and implications of defining children as agitated.

The first point refers to the blurred limits between scientific and popular categories, normal and abnormal behaviors, the responsibility of institutions in child care, and the extent of institutions' authority to identify, define, explain and solve what is considered to be a problem. The multiple uses of the term "agitation" reflect what we could consider a diffuse and vague category, neither pathological nor normal but natural (biologically) and at the same time social and cultural, employed to explain, organize, and normalize something that "is not working so well".

The circulation of the different concepts of agitation reveals, on the one hand, the banalization of biomedical categories in the common-sense discourse, and on the other, the ambiguity of biomedical discourse to clearly define clinical symptoms of some mental disorders, especially when they are referred to children's behavior. In this regard, historical, social and cultural notions of children, childhood and their behaviors are also identified in the speeches of health professionals by the integration of popular concepts of agitation.

The lack of a clear frontier limiting biological, social and cultural categories puts into question how these categories are related in the different notions of agitation, especially when also considering the social actors and institutions responsible for identifying, defining and treating children's behaviors. Thus, the phenomenon currently observed regarding agitation - as a vague concept with different uses -, is not dichotomic, but marked by the discussion about an interdependent and interchanging relationship between biological and sociocultural categories, in which "old oppositions, such as the dispute of biological determination over the social, or vice versa, do not seem to make sense" (Nakamura, 2017, p. 179, authors' translation).

The second point regards the social (adult) model that defines what a well-adapted child is, as well as the great range of expectations about children's behavior and performance. Thus, the definition of agitation cannot be separated from the definition each society has about children and their behaviors.

In this regard, to discuss children's behaviors in a particular society is also to consider the norms from which their behaviors are classified as normal, abnormal or pathologic. The conformity of a child to a social order, according to moral values and social expectations is complemented by the possibility of restating to the norm those who are out of it (Canguilhem, 1978).

Many child care institutions (family, school, health and social assistance services) have affirmed, over history, their role of keeping children within the ruling social norms and values based on scientific and specialized knowledge to guide professionals' practices. These child-oriented practices were usually related to the idea of socialization that considers that children must be socially and emotionally adjusted to an established order (Silva; Nunes, 2002) according to disciplinary strategies.

We ask, however, about the responsibility of these institutions and their efficacy in adjusting agitated children to an established order in contemporary societies. In other words, the question we ask regards the possibility of defining what institutions are responsible for the socialization process, especially when the frontiers of their practices and actions on agitation seem to be so unclear, as observed in the demands presented by the social actors and institutions to the studied CMHS. It seems that we are not facing adults' authority to impose a disciplinary socialization to children anymore, but we are in a context where the interdependent relationship between adults and children considering their autonomy - could be considered; thus, assuming that children are also "capable of making choices, taking initiative and being agents of their own change" (Nakamura; Planche; Ehrenberg, 2018, p. 419).

This leads us to the third point: the place of children in the process where their behaviors are identified as problematic, considering them as social actors in an interdependent relationship with 
adults, in addition to mediating and performing the experiences towards "agitation".

On the one hand, agitation as a concept can indicate children who diverge from an accepted social model of childhood and children's behavior; on the other hand, it can also create a new identity, sometimes proposed by adults, sometimes by children themselves. In the first case, the idea of "being ADHD" (Silva, 2003) or the assumption that ADHD and its symptoms are a personal characteristic underlies the speeches of some psychiatrists from CMHS1 in Campinas who define ADHD as a child mental disorder according to the biomedical discourse. They assume that ADHD is not a physiological dysfunction but define their symptoms as an impairment or a "personal characteristic" responsible for children's disadvantages in standardized school tasks and tests, as well as in other social activities, according to a psychiatrist interviewed at CMHS1.

In the second case, the ADHD diagnosis and treatment lead children attended in the CMHS1 to create or manage identities according to three manners of appropriation of the medical category. In the first one, a boy contested the medical "diagnosis" and the identity related to ADHD imposed by adults. He stated that he was not sick; thus, having no need to go to the doctor. However, the medical consultations were used as a justification to allow him to be absent from school. In the second manner the identity is related to the social model of well-adapted children. In this case, medication could be used by children at CMHS1 to manage their "spoiled identity" (Goffman, 1963), because it would allow them "stay calm", "to be like the others", and "not to be ashamed" about their different behavior. Finally, in the third manner of appropriation, the definition of ADHD symptoms is in the basis of an identity created to justify problematic behaviors. Responding to his ADHD condition, experiencing prejudice and the fear people have of his reactions, a boy from CMHS1 defined himself as a patient in a child psychiatry service, who has hyperactivity and does not stop even for a minute. He stated that my family asks me to stop and to be quiet, but I'm hyperactive; I can't be quiet, thus reinforcing his "hyperactive" identity.

Thus, reflecting on the meanings of defining children's behavior as agitated is not merely discussing the concepts related to this vague category, it implies the comprehension of the intentions, opinions and identities of those who experience ADHD, as exemplified above. We sought to show, briefly, how children can differently assimilate the medical categories and create new coping mechanisms or new identities.

Therefore, ADHD cannot be restricted to a diagnostic category, it must be understood as a biomedical construction that constitutes a fact, the "ADHD fact" (Caliman, 20o9), that reveals an intersection of concepts, knowledge, practices, institutions and social actors, including children themselves. According to the author, in the "ADHD fact" "dissonant voices that discuss - explicitly and implicitly - with biomedical speeches also constitute the pathology" (p. 136, authors' translation).

This discussion does not seek to deny the diagnostic categories, but to also consider them as a sociocultural phenomenon, integrating an interdependent and interchangeable network where the flows and the uses of concepts, knowledge, practices, persons (humans) and objects (nonhumans) must be considered to an in-depth understanding from a sociocultural perspective. Furthermore, when considering the "ADHD fact", the most important aspect is how children are considered as subjects who integrate such "fact".

If in the past children and their behavior were considered as diagnosis objects in terms of adults' expectations about children's behavior and performance, seeking a well-adapted child, currently they are requested to develop the capacity to control themselves. Given this context of changes, in-depth studies considering children's views about their relationship with adults are required, studies in which children are the subjects and agents of their own experiences. Concomitantly, we must comprehend their new social places and roles as they constitute their particular identities, contesting, being adapted or reinforcing "being ADHD". 


\section{References}

APA - AMERICAN PSYCHIATRIC ASSOCIATION. Diagnostic and statistical manual of mental disorders. 5. ed. Washington, DC, 2013.

ANDRADE, E. R.; SCHEUER, C. Análise da eficácia do metilfenidato usando a versão abreviada do Questionário de Conners em Transtorno de Déficit de Atenção/Hiperatividade. Arquivos de Neuropsiquiatria, São Paulo, v. 62, n. 1, p. 81-85, 2004 .

BARBARINI, T. A. A condição da criança hiperativa e desatenta: um estudo sobre a intervenção psiquiátrica nas formas contemporâneas de inserção social infantil. 2016. Tese (Doutorado em Sociologia) - Universidade Estadual de Campinas, Campinas, 2016.

BARBARINI, T. A. O controle da infância: caminhos da medicalização. 2011. Dissertação (Mestrado em Sociologia) - Universidade Estadual de Campinas, Campinas, 2011.

BUSTAMANTE, V.; MCCALLUM, C. Cuidado e construção social da pessoa: contribuições para uma teoria geral. Physis, Rio de Janeiro, v. 24, n. 3 , p. 673-692, 2014.

CALIMAN, L. V. A constituição sócio-médica do "fato TDAH". Psicologia \& Sociedade, Belo Horizonte, v. 21, n. 1, p. 135-144, 2009.

CANGUILHEM, G. O normal e o patológico. Rio de Janeiro: Forense-Universitária, 1978.

CAPONI, S. O DSM-V como dispositivo de segurança. Physis, Rio de Janeiro, v. 24, n. 3, p. 741-763, 2014.

CARDOSO DE OLIVEIRA, R. O trabalho do antropólogo. 3. ed. Brasília, DF: Paralelo 15; São Paulo: Ed. Unesp, 2006.

ELIAS, N. La société des individus. Paris: Fayard, 1991.

FERNANDES, H. R. Infância e modernidade: doença do olhar. In: GHIRALDELLI JUNIOR, P. (Org.). Infância, escola e modernidade. São Paulo: Cortez; Curitiba: Ed. UFPR, 1997. p. 61-82.
GOFFMAN, E. Stigma: notes on the management of spoiled identity. Englewood Cliffs: PrenticeHall, 1963.

HART, N.; GRAND, N.; RILEY, K. Making the grade: the gender gap, ADHD and the medicalization of boyhood. In: ROSENFELD, D.; FAIRCLOTH, C. A. Medicalized masculinities. Philadelphia: Temple University Press, 2006. p. 132-164.

LATOUR, B. Faturas/fraturas: da noção de rede à noção de vínculo. Ilha, Florianópolis, v. 17, n. 2, p. 123-146, 2015 .

NAKAMURA, E. Depressão na infância: uma abordagem antropológica. São Paulo: Hucitec: Fapesp, 2016.

NAKAMURA, E. Les problèmes de santé mentale durant l'enfance à Santos (Brésil) et Paris:

l'interdépendance entre biologique et social dans les comportements des enfants. In: LEMERLE, S.; REYNAUD-PALIGOT, C. (Coord.). La biologisation du social: discours et pratiques. Paris: Presses Universitaires de Paris Naterre, 2017. p. 161-18o.

NAKAMURA, E.; BARBARINI, T. A. Dealing with agitation in children by the mental health services and schools in the Brazilian cities of Santos and Campinas: concepts, care demands and referrals. In: WORKSHOP ENFANTS AGITES, PARCOURS MOUVEMENTES : VERS UNE COMPARAISON ENTRE EUROPE ET AMERIQUE DU SUD, 24 jan. 2017, Paris, França. Proceedings... Vanves: Institut des Amériques, 2017.

NAKAMURA, E.; PLANCHE, M.; EHRENBERG, A. The social aspects in the identification of children's mental health problems in two health services in Paris, France. Interface, Botucatu, v. 22, n. 65, p. 411-422, 2018.

OMS - ORGANIZAÇÃO MUNDIAL DA SAÚDE. Centro Colaborador da OMS para a Classificação de Doenças em Português. Classificação estatística internacional de doenças e problemas relativos à saúde. $10^{\mathrm{a}}$ rev. São Paulo, 2008. v. 1. Disponível em: <https://bit.ly/2UvkNwd>. Acesso em: 3 mar. 2011. 
PINELL, P.; ZAFIROPOULOS, M. La medicalization de l'échec scolaire. Actes de la Recherché en Sciences Sociales, Paris, v. 24, p. 23-49, 1978.

ROHDE, L. A.; HALPERN, R. Transtorno de déficit de atenção/hiperatividade: atualização. Jornal de Pediatria, Porto Alegre, v. 8o, n. 2, p. S61-S7o, 2004. Suplemento.

SILVA, A. B. B. Mentes inquietas: entendendo melhor o mundo das pessoas distraídas, impulsivas e hiperativas. São Paulo: Gente, 2003.

SILVA, A. L.; NUNES, A. Contribuições da etnologia indígena à antropologia da criança. In: SILVA, A. L.; MACEDO, A. V. L.; NUNES, A. (Org.). Crianças indígenas: ensaios antropológicos. São Paulo: Global, 2002. p. 11-33. (Coleção Antropologia e Educação).
SILVERMAN, D. (Ed.). Qualitative research. 3. ed. London: Sage Publications, 2010.

SINGH, I. Doing their jobs: mothering with Ritalin in a culture of mother-blame. Social Science \& Medicine, Oxford, v. 59, p. 1193-1205, 2004 .

SINGH, I. Not just naughty: 50 years of stimulant drug advertising. In: TONE, A.; WATKINS, E. (Org.). Medicating modern America: prescription drugs in history. New York: New York University Press, 2007. p. 131-155.

VASCONCELOS, M. M. et al. Prevalência do transtorno de déficit de atenção/hiperatividade numa escola pública primária. Arquivos de Neuropsiquiatria, São Paulo, v. 61, n. 1, p. 67-73, 2003.

\section{Authors' contribution}

Nakamura was responsible for the critical review and approval of the final version. Barbarini collaborated with the article's critical review. Both authors analysed data and contributed to the manuscript's writing.

Received: $12 / 17 / 2018$

Approved: $12 / 28 / 2018$ 